\title{
The influence of tropical and subtropical air masses on the chemical composition of the tropospheric aerosol of Western Siberia based on the results of systematic aircraft sounding in 1997-2017
}

\author{
Denis Simonenkov*, Boris Belan, Gennadii Tolmachev, and Tatyana Rasskazchikova \\ V.E. Zuev Institute of Atmospheric Optics SB RAS (IAO SB RAS), 634055 Tomsk, Russia
}

\begin{abstract}
Almost monthly sensing of the troposphere from 500 to $7000 \mathrm{~m}$ above Karakansky bor (Novosibirsk Province) are conducted since 1997 up to now by using of the aircraft-laboratory "Optik" based on Antonov-30 or Tupolev-134. Aerosol sampling on to Petryanov filters AFA-CP20 for subsequent laboratory quantitative analysis of the content of inorganic ions and the next elements in the aerosol composition: $\mathrm{Al}, \mathrm{Ba}, \mathrm{Ca}, \mathrm{Cu}, \mathrm{Fe}, \mathrm{Mg}, \mathrm{Mn}, \mathrm{Mo}, \mathrm{Ni}, \mathrm{Pb}, \mathrm{Sn}, \mathrm{Ti}, \mathrm{V}, \mathrm{Be}, \mathrm{Cd}, \mathrm{Si}$, $\mathrm{Co}, \mathrm{Cr}, \mathrm{Sr}, \mathrm{Zn}, \mathrm{Zr}$ was performed for each flight. For the region of the study of tropospheric aerosol, the chemical composition of the aerosol was classified for the main air masses during the period of airborne sounding from September 1997 to June 2017 - continental arctic, continental moderate, and combined into one "southern" group of the continental tropical and subtropical air masses. Explicit "southern" origin, along with silicon, have chromium, manganese, silver and bicarbonate-anion. To the same group, the ions of chlorine and sodium are attracted, which probably were transported together with salt particles originating from Central Asian deserts.
\end{abstract}

\section{Introduction}

The main source of natural aerosol is the desert, occupying about $30 \%$ of the Earth land area. With respect to the study area centered over the southern part of Novosibirsk region $\left(82.25^{\circ} \mathrm{E}, 54.35^{\circ} \mathrm{N}\right)$, obviously, air masses of southern origin passing through the Central Asian region will exert the maximum influence, first of all, from the Central Asian deserts and semi-deserts on the Siberian region. Aerosol, brought with tropical and subtropical air masses, will be formed to the greatest extent by desert removals.

As rule monthly sensing of the troposphere from 500 to $7000 \mathrm{~m}$ above Karakansky bor (pine forest), located south-west of Novosibirsk on the right bank of the Novosibirsk reservoir near the border with the Altai region, was conducted since 1997 up to 2010 with using the "Optik-E" Antonov-30 aircraft-laboratory [1], and with "Optik" using Tupolev-134 after 2010 [2]. The soundings were carried out in clear or slightly cloudy weather. Complex equipment includes contact and remote devices and sensors that measure the gas and aerosol composition of the atmosphere at different altitudes, while controlling the meteorological variables and navigation parameters. Specially developed software is collecting, processing, control and visualization of measured values on the aircraft laboratory.

\section{Sites and Methods}

Airborne sounding of the atmosphere on aircraft laboratory "Optik" held since 1997, with an almost monthly basis in the tropospheric layer up to $7 \mathrm{~km}$ above Karakansky bor (conditionally background area), located 100-200 km south-west of Novosibirsk on the border with the Altai region. The typical flight route map is shown on Fig. 1.

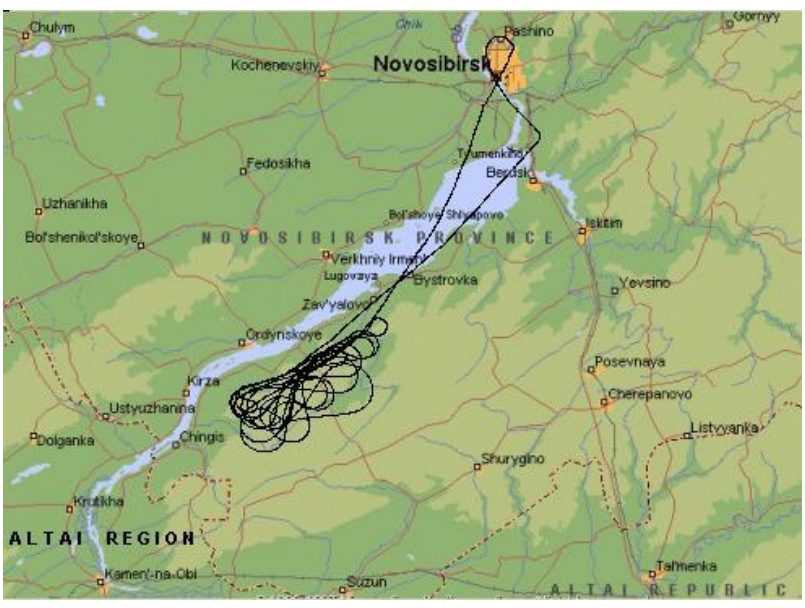

Fig. 1. Horizontal track of typical flight of the "Optik" Tupolev-134 aircraft-laboratory on the map of Novosibirsk region (March 2011) 
During such flights, among other things, sampling of atmospheric aerosol is carried out on Petryanov's filters (AFA-ChP-20). The subsequent quantitative physical and chemical analysis for the content in the aerosol matrix of the main inorganic components - all terrigenous and microelements, and also inorganic ions: $\mathrm{Si}, \mathrm{Al}, \mathrm{Fe}, \mathrm{Mg}, \mathrm{Ca}, \mathrm{Ti}, \mathrm{Cu}, \mathrm{Mn}, \mathrm{Pb}, \mathrm{Cr}, \mathrm{Ag}, \mathrm{Ni}, \mathrm{V}, \mathrm{Ba}$, Mo, $\mathrm{B}, \mathrm{Co}, \mathrm{Be}, \mathrm{K}^{+}, \mathrm{Na}^{+}, \mathrm{Cl}^{-}, \mathrm{SO}_{4}{ }^{2-}, \mathrm{NO}_{3}^{-}$, in certain periods $-\mathrm{NH}_{4}{ }^{+}, \mathrm{Br}^{-}, \mathrm{F}^{-}, \mathrm{HCO}_{3}{ }^{-}$- are performed in the analytical chemical laboratory of the Tomsk State University after one-year series of flights. Over 20 years, more than 1,000 samples from this region were sampled and analyzed.

\section{Results}

Synoptic analysis of all sampling cases for the period under review, drawn by baric topography maps, showed the following distribution (\%) over air masses (fig.2).

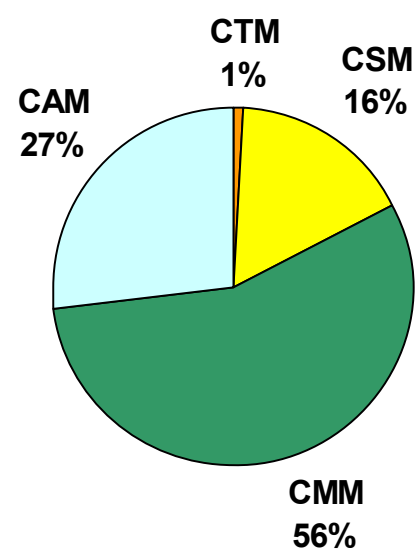

Fig. 2. The relative number of sampling cases (\%) for different air masses (CAM - Continental Arctic, CMM - Continental Moderate, CSM - Continental Subtropical and CTM Continental Tropical air masses)

The tropical and subtropical air masses responsible for the entry into the atmosphere of Siberia of a desert aerosol are combined into one group to calculate the statistical characteristics (Table 1, the last column).

Table 1. Statistics of samples for each air mass and chemical component (ion or element) used to calculate the mean values and confidence interval for each component in the selected air masses (CAM - Continental Arctic, CMM - Continental Moderate, CSTM - Continental subtropical and tropical)

\begin{tabular}{|c|c|c|c|}
\hline Ion/Elem. & CAM & CMM & CSTM \\
\hline $\mathrm{Na}^{+}$ & 228 & 435 & 139 \\
\hline $\mathrm{K}^{+}$ & 217 & 415 & 127 \\
\hline $\mathrm{SO}_{4}^{2-}$ & 207 & 370 & 117 \\
\hline $\mathrm{Cl}^{-}$ & 253 & 516 & 157 \\
\hline $\mathrm{NO}_{3}{ }^{-}$ & 215 & 433 & 135 \\
\hline $\mathrm{NH}_{4}{ }^{+}$ & 88 & 161 & 67 \\
\hline $\mathrm{Br}^{-}$ & 54 & 164 & 28 \\
\hline $\mathrm{F}^{-}$ & 11 & 46 & 13 \\
\hline $\mathrm{HCO}_{3}{ }^{-}$ & 13 & 43 & 7 \\
\hline
\end{tabular}

\begin{tabular}{|c|c|c|c|}
\hline $\mathrm{Ca}^{2+}$ & 8 & 32 & 8 \\
\hline $\mathrm{Mg}^{2+}$ & 9 & 30 & 6 \\
\hline $\mathrm{Mg}$ & 238 & 511 & 154 \\
\hline $\mathrm{Fe}$ & 235 & 488 & 158 \\
\hline $\mathrm{Al}$ & 266 & 551 & 170 \\
\hline $\mathrm{Si}$ & 237 & 518 & 162 \\
\hline $\mathrm{Ca}$ & 250 & 527 & 158 \\
\hline $\mathrm{Cu}$ & 231 & 495 & 170 \\
\hline $\mathrm{Mn}$ & 207 & 467 & 151 \\
\hline $\mathrm{Cr}$ & 204 & 426 & 159 \\
\hline $\mathrm{Ti}$ & 202 & 449 & 138 \\
\hline $\mathrm{Ni}$ & 198 & 426 & 143 \\
\hline $\mathrm{Pb}$ & 185 & 403 & 136 \\
\hline $\mathrm{V}$ & 127 & 232 & 91 \\
\hline Mo & 141 & 268 & 111 \\
\hline $\mathrm{Ba}$ & 150 & 306 & 125 \\
\hline $\mathrm{Sn}$ & 115 & 245 & 103 \\
\hline Co & 109 & 202 & 91 \\
\hline B & 81 & 149 & 35 \\
\hline $\mathrm{Ag}$ & 49 & 81 & 24 \\
\hline $\mathrm{Zn}$ & 94 & 159 & 91 \\
\hline $\mathrm{Cd}$ & 45 & 114 & 42 \\
\hline $\mathrm{Be}$ & 53 & 131 & 46 \\
\hline $\mathrm{Zr}$ & 68 & 140 & 58 \\
\hline $\mathrm{Sr}$ & 50 & 98 & 24 \\
\hline $\mathrm{Sb}$ & 8 & 2 & - \\
\hline
\end{tabular}

In view of the fact that, like the dispersed composition of the aerosol, the distribution of chemical component concentrations obeys the lognormal law, the mean values and standard deviations were calculated for logarithms of concentrations for which the confidence interval at the level $\mathrm{P}=0.95$ was then considered. Thus, the average values and boundaries of the confidence intervals plotted on the graphs of Figures 3 and 4 are the antilograms of the obtained values.

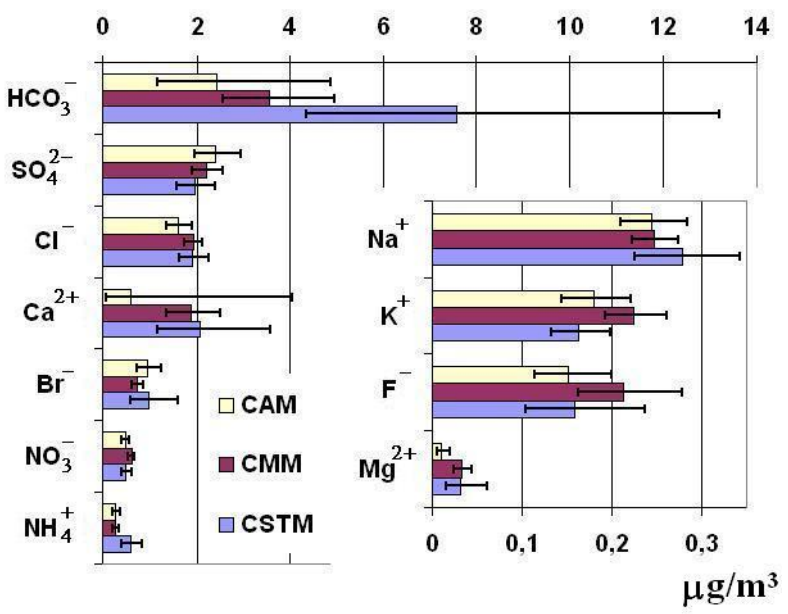

Fig. 3. The mean geometric values of the ion concentrations in the Karakansky bor region in different types of air masses (confidence intervals at the level of $\mathrm{P}=0.95$ are also calculated from the root-mean-square deviations calculated for the logarithms of concentrations) 

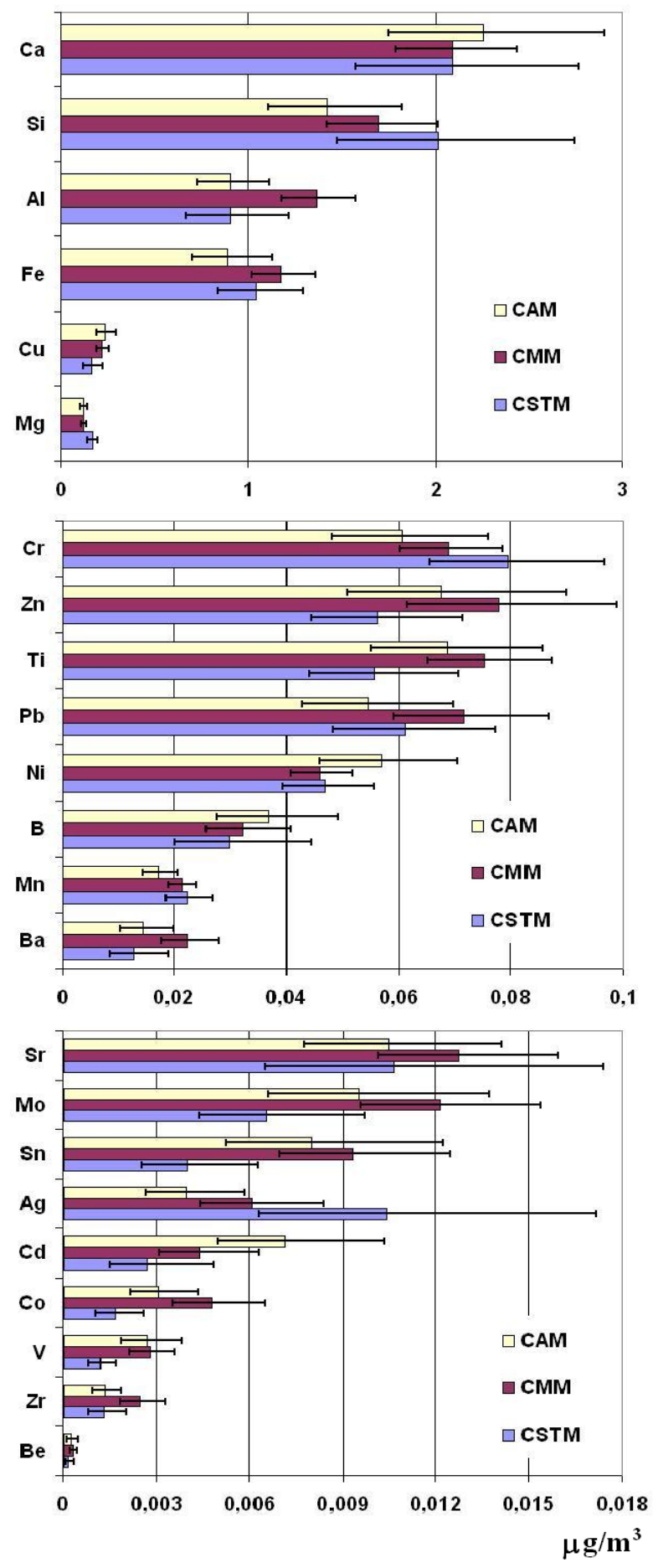

Fig. 4. The mean geometric values of the concentrations of elements in the Karakansky bor region in different types of air masses (confidence intervals at the level of $\mathrm{P}=0.95$ are also calculated from the root-mean-square deviations calculated for the logarithms of concentrations)

\section{Conclusions}

Statistical analysis of the chemical composition of the aerosol by the air mass criterion makes it possible to draw the following preliminary conclusions on the latitudinal laws of the origin of individual elements and inorganic ions, combining them according to this feature into the appropriate groups.
The trace elements of copper, boron, cadmium, nickel and sulfate anion have a direct correlation with the breadth of origin of the air mass. Obviously, all these components have a significant anthropogenic contribution, confirming the high accumulation capacity of the Arctic air [3].

Continental moderate air forms the most numerous group of elements and ions in the tropospheric aerosol of the south of Western Siberia: aluminum, iron, zinc, titanium, lead, barium, strontium, molybdenum, tin, cobalt, vanadium, zirconium, from ions - potassium, fluoride and nitrate [4]. Obviously, a moderate mass has a local or zonal origin, therefore, considering the dominant currents, it is possible to predict the main contribution of the western regions - the Urals and North Kazakhstan, as well as the Kuzbass and, in some cases, the central regions of the East Siberian plateau.

Explicit "southern" origin, along with silicon, have chromium, manganese, silver and bicarbonate-anion. The conclusion about the last in this series component, however, has a low statistical supply for warm air masses, although they give the most pronounced peak concentration for $\mathrm{HCO}_{3}{ }^{-}$. To the same group, the ions of chlorine and sodium are attracted, which transport together with salt particles of Central Asian deserts.

Further elaboration of individual groups of cases of synoptic formations within each air mass will make it possible to substantially clarify the regularities of their influence on the aerosol field of impurities in the region under study and to reveal new factors in the formation of aerosol and gas fields in the inland continental region of the south of Western Siberia as a whole.

The study was supported, in part, by the Russian Scientific Foundation Project No.17-17-01095.

\section{References}

1. P. N. Antokhin, M. Yu. Arshinov, B. D. Belan, D. K. Davydov, E. V. Zhidovkin, G. A. Ivlev, A. V. Kozlov, V. S. Kozlov, M. V. Panchenko, I. E. Penner, D. A. Pestunov, D. V. Simonenkov, G. N. Tolmachev, A. V. Fofonov, V. S. Shamanaev, V. P. Shmargunov, J. Atmos. Ocean. Technol. 29, 64-75 (2012)

2. G.G.Anokhin, P.N.Antokhin, M.Yu.Arshinov, V.E.Barsuk, B.D.Belan, S.B.Belan, D.K.Davydov, G.A.Ivlev, A.V.Kozlov, V.S.Kozlov, M.V.Morozov, M.V.Panchenko, I.E.Penner, D.A.Pestunov, G.P.Sikov, D.V.Simonenkov, D.S.Sinitsyn, G.N.Tolmachev, D.V.Filipov, A.V.Fofonov, D.G.Chernov, V.S.Shamanaev, V.P.Shmargunov, Atmos. Ocean. Opt. 24, 805-816 (2011)

3. A.A.Vinogradova, V.P.Shevchenko, Atmos. Ocean. Opt. 24, 344-349 (2005)

4. A.P.Sukhodolov, N.I.Ianchenko, A.V.Talovskaya, E.G.Yazikov, Ecology and Industry of Russia 22, 51-55 (2018) 